第 10 回日本医学シミュレーション学会特別企画

日臨麻会誌 Vol.36 No.2, $230 ～ 235,2016$

周術期二次救命処置トレーニング (ALS-OP)の必要性

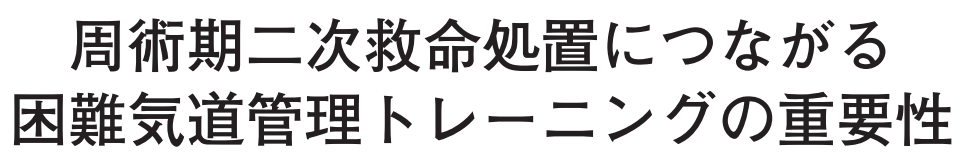

駒澤伸泰*1 $\quad$ 羽場政法*2 藤原俊介*1 $^{*}$ 上嶋浩順 ${ }^{3}$ 五十嵐 寛 ${ }^{*}$ 南 敏明*1

[要旨] 予期せぬ挿管不能・換気不能 (cannot intubate, cannot ventilate : CICV)の解除は二 次救命処置の範疇に含まれるといえる. 挿管不能・換気不能を形成する因子は患者の気道解剖だけ でなく, 生理的状況や麻酔科医の技量, 手術室の環境因子なども含まれる. 予期せぬCICVへの対 応は麻酔科医の気道管理に関連した技術的能力だけでなくノンテクニカルスキルの習得が重要であ る. このようなノンテクニカルスキル養成のために気道管理に関連した周術期二次救命処置トレー ニング(ALS-OP)が有効な可能性がある. 本稿ではALS-OP気道編の内容と可能性について紹介 する.

キーワード : 予期せぬ挿管不能・換気不能, ノンテクニカルスキル, 二次救命処置

\section{I 挿管不能・換気不能の原因は多種多様}

麻酔科医が最も対応に難渋するのは術前に挿管困 難や換気困難が予測されるケースではなく，「予期 せ女挿管不能・換気不能 (cannot intubate, cannot ventilate : CICV)」である。予期せ女挿管不能・換 気不能は心停止に直結するため CICV の解除は二次 救命処置の範疇に含まれるといえる ${ }^{1), 2}$.

抻管不能・換気不能を形成する因子は患者の気道 解剖だけでなく, 生理的状況や麻酔科医の技量, 手 術室の環境因子なども含まれる。手術室の環境因子 として各種気道確保器具の整備不良だけでなく, リ ークテストの急慢や麻酔器の故障によるものも考え られる。また, 生理的な原因で換気不能に陥る原因 としては, 喉頭痤攣, 気管支痤攣, 喘息発作や, 誤

${ }^{{ }^{1} 1}$ 大阪医科大学麻酔科学教室

*2国保日高総合病院麻酔科

${ }^{* 3}$ 昭和大学病院麻酔科

*4浜松医科大学臨床医学教育学
曣による酸素化不良も鑑別する必要がある。実臨床 では，解剖学的な気道管理困難だけではなく，これ らの要素も生命危機に直結する「予期せ女 CICV」 の原因となることに留意すべきである(図1).

予期せ女 CICVへの対応は麻酔科医の気道管理に 関連した技術的能力だけでなく麻酔科医およびメデ イカルスタッフの総合的な臨床能力が必要とされ る。このようなトレーニングではテクニカルスキル だけではなくノンテクニカルスキルの習得が重要で ある。

われわれはこのような二次救命処置に通じる困難 気道管理トレーニングとして PBLD (problem-based learning discussion)形式の気道管理トレーニング (ALS-OP気道編)を開発，開催している ${ }^{3)}$.4)。本稿 ではALS-OP気道編の概略と学習目標について述

著者連絡先 駒澤伸泰

干 569-8686 大阪府高槻市大学町 $2-7$ 大阪医科大学麻酔科学教室 


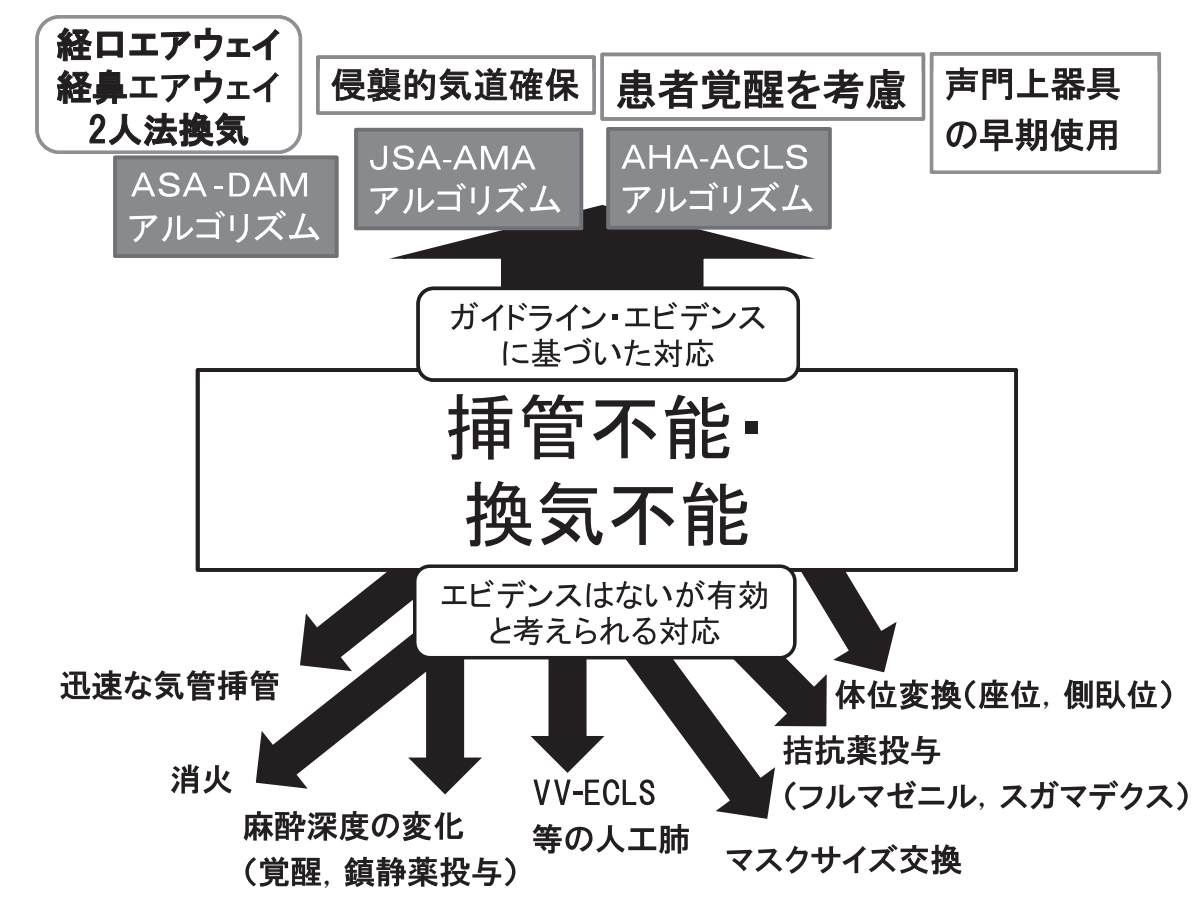

図1 挿管不能・換気不能の事態に考えられるさまざまな対応

ベる.

\section{ALS-OP気道編の開発}

ALS-OPの作成には「分析，設計，開発，実施， 再評価」の教育工学的なアプローチを重視する体系 的な教育技法である教育工学 (instructional system design : ISD)を重視した。まず日本麻酔科学会の麻 酔科医教育ガイドラインと麻酔関連偶発症例調査か ら表1のようにシナリオと学習目標を策定した ${ }^{5), 6)}$. 気道管理のシナリオの内容は, 気道管理関連では換 気不能による心停止の予防や対応を第一とした。し かし，気道管理に関する危機的状況は解剖学的気道 管理困難だけではなく，アナフィラキシーショック や喘息発作などの生理的状況に基づく換気不能の解 除や，気道火災や抜管後の喉頭痓攣などの医療行為 が原因となる気道管理由来の急変管理も含めた ${ }^{7,8)}$. コース運営に関しては，DAM実践セミナーのよう にシミュレーターを用いることも検討したが9， テ クニカルスキルよりも，ノンテクニカルスキルを重
視することから米国心㵴協会が主催する ACLS-EP コースを参考にPBLD形式を採用した。さらに適宜, 米国麻酔科学会の困難気道，火災予防，術前絶飲食 のガイドラインを引用した ${ }^{1), 8}$.

また, PBLDを進める際も, 症例提示からリスク 評価・準備，そして急変時の鑑別と対応について検 討した。さらにデブリーフィングを行うことで自身 の臨床へのフィードバックや気付きを得られるよう に留意した(図2 $)^{10)}$, 11).

\section{ALS-OP気道編シナリオの内容}

現在作成している7つのシナリオと学習目標を提 示する。

\section{(1)全身麻酔導入時の換気不能}

本シナリオはALS-OP気道編の全身麻酔導入後 の換気不能とLMAによる解除である。しかし，典 型的な上気道閉塞による換気不能だけでなく，喉頭 痤攣，気管支喘息発作などの生理的要因等の換気不 能を誘発するさまざまな原因の鑑別をしてもらつ 
表1 ALS-OP気道編のシナリオ, 学習目標と参照ガイドライン

\begin{tabular}{|c|c|c|c|}
\hline シナリオのテーマ & 内容 & 学習目標 & 参照されるガイドライン \\
\hline $\begin{array}{l}\text { (1)全身麻酔導入時の } \\
\text { 換気不能 }\end{array}$ & $\begin{array}{l}\text { 全身麻酔導入後の換気不能と } \\
\text { LMAによる解除 }\end{array}$ & $\begin{array}{l}\text { 換気不能を誘発するさまざま } \\
\text { な原因の鑑別 }\end{array}$ & ASA-DAM ガイドライン \\
\hline $\begin{array}{l}\text { (2)全身麻酔導入時の } \\
\text { 気管挿管不能 }\end{array}$ & $\begin{array}{l}\text { 全身麻噵入後の開口困難, そ } \\
\text { の後捙管操作中に換気不能とな } \\
\text { り輪状甲状膜穿刺 }\end{array}$ & $\begin{array}{l}\text { 予期せぬ挿管困難 } \\
\text { 換気不能と侵襲的気道確保の } \\
\text { 適応 }\end{array}$ & ASA-DAM ガイドライン \\
\hline $\begin{array}{l}\text { (3)困難気道が } \\
\text { 予測される場合の } \\
\text { 意識下挿管 }\end{array}$ & $\begin{array}{l}\text { 意識下挿管時に過鎮静となり換 } \\
\text { 気不能 } \\
\Rightarrow \text { 掩管用声門器具を通して捚管 }\end{array}$ & $\begin{array}{l}\text { 意識下挿管時に必要な鎮静深 } \\
\text { 度と気道管理 } \\
\text { 挿管用声門上器具の意義 }\end{array}$ & $\begin{array}{l}\text { ASA-DAM ガイドライン } \\
\text { ASA-SED ガイドライン } \\
\text { ASA-術前絶飲食ガイドライン }\end{array}$ \\
\hline $\begin{array}{l}\text { (4)全身麻酔導入時の } \\
\text { アナフィラキシーへの } \\
\text { 対応 }\end{array}$ & $\begin{array}{l}\text { 筋弛緩薬投与後にアナフィラキ } \\
\text { シーショョ発生し換気不能 }\end{array}$ & $\begin{array}{l}\text { アナフィラキシー門・声帯浮腫への対応と治療 } \\
\end{array}$ & $\begin{array}{l}\text { ASA-DAM ガイドライン } \\
\text { AHA-ACLS ガイドライン }\end{array}$ \\
\hline (5)術中喘息発作への対応 & $\begin{array}{l}\text { 全身麻酔導入後に喘息発作が } \\
\text { 発生し換気不能となる }\end{array}$ & 術中喘息発作の対応と鑑別 & $\begin{array}{l}\text { ASA-DAM ガイドライン } \\
\text { AHA-ACLSガイドライン }\end{array}$ \\
\hline 66気道火災への対応 & $\begin{array}{l}\text { 気道火災による換気不能と対応 } \\
\text { について学ぶ }\end{array}$ & $\begin{array}{l}\text { 手術室火災, 特に気道火災へ } \\
\text { の対応 }\end{array}$ & $\begin{array}{l}\text { ASA-DAM ガイドライン } \\
\text { ASA-火災予防ガイドライン }\end{array}$ \\
\hline (7)抜管後の喉頭痙攣 & $\begin{array}{l}\text { 困難気道症例の覚醒時に喉頭 } \\
\text { 痙攣が発生 }\end{array}$ & 困難気道症例の抜管準備 & ASA-DAM ガイドライン \\
\hline
\end{tabular}

た.さらに各施設による換気不能時の対応について ディスカッションすることで理解を深めた。

(2)全身麻酔導入時の気管挿管不能

全身麻酔導入後の開口困難，その後抻管操作中に 換気不能となり輪状甲状膜穿刺を行うシナリオであ る。学習目標としては, 予期せ女抻管困難に対する 対応や插管困難症例での換気不能すなわち CICV へ の対応である. シナリオの最後のディスカッション では各自の困難気道管理時の換気についてのディス カッションを行った。

(3)困難気道が予測される場合の意識下挿管

このシナリオは, 自発呼吸温存で軽度鎮静を目指 した意識下挿管時に過鎮静となり換気不能となる症 例である。挿管用声門上器具で換気を確立した後, 気管挿管につなげるシナリオである。学習目標とし ては，意識下挿管時に必要な鎮静深度について考え ることと換気と挿管をつなぐ挿管用声門上器具の意 義を学ぶことである. シナリオ後のデブリーフィン グでは，米国麻酔科学会の鎮静ガイドラインをもと に意識下挿管に関する適切な鎮静深度についてのデ イスカッションを行った ${ }^{12)}$.
(4)全身麻酔導入時のアナフィラキシーへの対応

本シナリオは筋弛緩薬投与後にアナフィラキシー ショックが発生し換気不能となる症例である。学習 目標としては筋弛緩薬投与による上気道閉塞のみな らずアナフィラキシーによる声門・声帯浮腫による 気道閉塞を鑑別する必要がある。米国心臓協会の二 次救命処置ガイドラインにおけるアナフィラキシー ショックの対応と麻酔科的に考えられるさまざまな 対応をデイスカッションし理解を深める7).

(5)術中喘息発作への対応

全身麻酔導入後に喘息発作が発生し換気不能とな るシナリオである。術中喘息発作の対応と鑑別を学 習目標としている。換気不能に陥るまでの喘息重積 発作は頻度的にも少ないかもしれないが，鑑別でき なければ死に至り，高圧での換気により気胸発生の 可能性もある。ディスカッションではそれぞれの受 講生の喘息発作の経験と施設の対応を討議した。

(6)気道火災への対応

本シナリオでは，気管切開中に発生する気道火災 による換気不能と対応について学ぶ。学習目標は, 手術室火災，特に気道火災への対応の基礎を身に付 


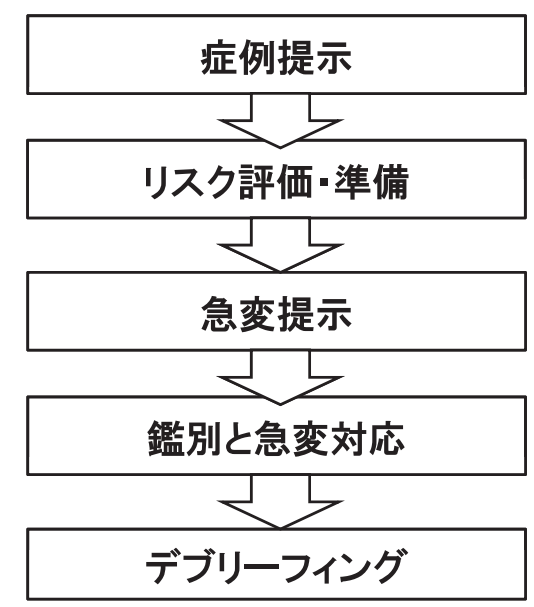

図2 ALS-OP気道編のシナリオの進め方

けることである。施設により対応はさまざまではあ るが，米国麻酔科学会の手術室火災対応ガイドライ ンをもとに, 予防と早期対応についてディスカッシ ヨンを加えた ${ }^{8)}$.

\section{(7)抜管後の喉頭痤攣}

本シナリオは，困難気道症例の覚醒時に喉頭瘥攣 が発生し対応する症例である。困難気道症例の抜管 準備だけでなくさまざまな気道閉塞，換気不能の原 因を鑑別することが学習目標である。ディスカッシ ヨンでは抜管時のさまざまな合併症やそれぞれの麻 酔科医の注意点について討議した。

\section{ALS-OP気道編の活用の今後}

われわれは ALS-OPの初期シナリオとしては成 人の周術期の気道管理に関して作成を行ったが，今 後は小児の緊急気道管理(先天性心疾患や扁桃摘出) や心肺蘇生中の気道管理等のシナリオを加えていく ことも有効かもしれない ${ }^{13)}{ }^{14)}$. また，コース受講が 受講生の意識に与える影響や学習効果の検討も必要 である ${ }^{15), 16)}$.

われわれは，ALS-OP気道編を当大学研修関連 病院の麻酔科の後期研修医を対象に開催したが，看 護師をはじめとするメディカルスタッフを含めた周 術期チームの教育にも有効な可能性がある ${ }^{17)}$.さら
に ALS-OPのシナリオ作成を各大学・組織だけで なく, 日本麻酔科学会全体で共有し共通の教育メy ッドとすることで相互交流やシナリオの質の向上, 学習効果の増大につながる可能性がある。

\section{結＼cjkstart語}

二次救命処置に通じる困難気道管理トレーニング としてPBLD形式の気道管理トレーニング(ALS-OP 気道編)を開発した。各施設におけるDAMトレー ニングだけでなく周術期気道管理に関する医療安全 に役立てば幸いである。

\section{参考文献}

1) Apfelbaum JL, Hagberg CA, Caplan RA, et al. : Practice guidelines for management of the difficult airway : an updated report by the American Society of Anesthesiologists Task Force on Management of the Difficult Airway. Anesthesiology 118 : 251-270, 2013

2) Hazinski MF, Nolan JP, Billi JE, et al. : Part $1:$ Executive summary : 2010 International Consensus on Cardiopulmonary Resuscitation and Emergency Cardiovascular Care Science With Treatment Recommendations. Circulation 122(Suppl 2) : S250-S275, 2010

3）駒澤伸泰, 羽場政法, 上嶋浩順ほか：専門領域に応用 できるALS コースの必要性一周術期 ALS (ALS-OP)の 提案一. 日臨麻会誌 $35: 538-543,2015$

4）駒澤伸泰, 藤原俊介, 羽場政法ほか：周術期二次救命処 置トレーニング(ALS-OP)の開催経験。麻酔 64:562565, 2015

5）入田和男, 川島康男, 嚴康秀ほか：「麻酔関連偶発症例 調查2002」および「麻酔関連偶発症例調查 1999-2002」 について：総論一(社) 日本麻酔科学会安全委員会偶発 症例調查専門部会報告一。麻酔 $53: 320-335,2004$

6) Neumar RW, Otto CW, Link MS, et al. : Part 8 : adult advanced cardiovascular life support : 2010 American Heart Association Guidelines for Cardiopulmonary Resuscitation and Emergency Cardiovascular Care. Circulation 122 (Suppl 3) : S729-S767, 2010

7) Vanden Hoek TL, Morrison LJ, Shuster M, et al. : Part 12 : cardiac arrest in special situations : 2010 American Heart Association Guidelines for Cardiopulmonary Resuscitation and Emergency Cardiovascular Care. Circulation 122 (Suppl 3) : S829-S861, 2010

8) Apfelbaum JL, Caplan RA, Barker SJ, et al. : Practice 
advisory for the prevention and management of operating room fires : an updated report by the American Society of Anesthesiologists Task Force on Operating Room Fires. Anesthesiology $118: 271-290,2013$

9）中川雅史, 野村岳志, 五十嵐寛ほか：Difficult Airway Management (DAM) 第 1 回実践セミナを実施して。麻 酔 $54: 557-562,2005$

10) Komasawa N, Sanuki T, Fujiwara S, et al. : Significance of debriefing methods in simulation-based sedation training courses for medical safety improvement in Japan. Springerplus $3: 637,2014$

11) Bhanji F, Mancini ME, Sinz E, et al. : Part 16 : education, implementation, and teams : 2010 American Heart Association Guidelines for Cardiopulmonary Resuscitation and Emergency Cardiovascular Care. Circulation 122 (Suppl 3) : S920-S933, 2010

12) Practice guidelines for sedation and analgesia by nonanesthesiologists. An updated report by the American Society of Anesthesiologists Task Force on Sedation and Analgesia by Non-Anesthesiologists. Anesthesiology $96: 1004-1017,2002$
13) Komasawa N, Ueki R, Yamamoto N, et al. : Comparison of air- $Q^{\varpi}$ and Soft Seal ${ }^{\varpi}$ laryngeal mask for airway management by novice doctors during infant chest compression : a manikin study. Resuscitation $83: 365^{-}$ 368, 2012

14) Komasawa N, Ueki R, Kohama H, et al. : Comparison of Pentax-AWS Airwayscope video laryngoscope, Airtraq optic laryngoscope, and Macintosh laryngoscope during cardiopulmonary resuscitation under cervical stabilization : a manikin study. J Anesth $25: 898-903$, 2011

15) Naik VN, Brien SE : Review article : simulation : a means to address and improve patient safety. Can J Anaesth $60:$ 192-200, 2013

16) Komasawa N, Fujiwara S, Atagi K, et al. : Effects of a simulation-based sedation training course on non-anesthesiologists' attitudes toward sedation and analgesia. J Anesth $28: 785-789,2014$

17）藤原俊介, 駒澤伸泰, 辰巳真一ほか：手術室内で行う SED 実践セミナー(セデーショントレーニングコース) の意義. 麻酔 $63: 934-937,2014$ 


\title{
Airway Management Training Should Include Advanced Life Support
}

\author{
Nobuyasu KOMASAWA*1, Masanori HABA ${ }^{* 2}$, Shunsuke FUJIWARA*1, \\ Hironobu UESHIMA*3, Hiroshi IGARASHI ${ }^{* 4}$, Toshiaki MINAMI*1 \\ ${ }^{* 1}$ Department of Anesthesiology, Osaka Medical College \\ ${ }^{* 2}$ Department of Anesthesiology, Hidaka General Hospital \\ ${ }^{* 3}$ Department of Anesthesiology, Showa University Hospital \\ ${ }^{* 4}$ Department of Medical Education, Hamamatsu University School of Medicine
}

Various airway management algorithms have shown that management of impossible ventilation is an essential component of airway management. In emergency situations that require securing the airway, supraglottic devices such as a laryngeal mask are recommended, and may necessitate invasive airway management. For example, anesthesiologists must secure the patient's airway as soon as possible during chest compression in case of cardiac arrest. Furthermore, there are several possible mechanisms for impossible ventilation such as anaphylactic reaction, severe asthma attack, or airway fire. We have developed several problem-based learning discussion type scenarios regarding serious airway problems related to impossible ventilation. Perioperative advanced life support simulation may be beneficial for training not only anesthesia residents but also medical staff in the operating room.

Key Words : CICV (cannot intubate, cannot ventilate), Non-technical skill, Advanced life support

The Journal of Japan Society for Clinical Anesthesia Vol.36 No.2, 2016 